\title{
Becoming Mountain
}

\author{
Tornar-se montanha
}

\begin{abstract}
Ian Buchanan*
University of Wollongong, New South Wales, Australia
\end{abstract}

\section{Abstract}

Like the concept of the assemblage, the body without organs is much written about, but unlike the assemblage there are no specific schools of thought associated with the body without organs, much less any agreed definitions. As such, it tends to be used in a very vague manner, with most accounts of it ignoring its practical dimension and instead focusing on its aesthetic (Artaud) and philosophical (Spinoza) origins. However, Deleuze quite explicitly positions the assemblage as a contribution to an understanding of behaviour, so the purely philosophical accounts of the body without organs that give no account of how it can be used analytically are not helpful in my view. I demonstrate that the practical conception of the body without organs is an effective way of understanding the concept. I use the example of George Mallory's attempt to climb Everest to illustrate this point. I argue that if we focus only on the symbolic attainment of being the first person to climb the world's tallest mountain and consign the actual act of climbing to the realm of mere entry price, then we effectively destroy the assemblage by rendering it teleological. Now, one might think that this means one should balance the 
equation by focusing on the bodily dimension of the climb, and certainly that is the direction we need to take, but to do that we need to conceive of a space where that physical dimension can be registered in something other than purely biological terms. If, as Spinoza and after him Deleuze have argued, we do not know what a body can do, it is because we do not have the conceptual means of capturing and expressing its capabilities. We can record its achievements, but we cannot map its capabilities because the body seems always to be capable of doing more than anyone thought possible. Until 1953 when Hillary and Norgay reached the peak of Everest climbing Everest was generally regarded as impossible. A view that was reinforced by the dozen or so failed attempts, not to mention the many deaths occasioned by those attempts, that preceded Hillary and Norgay' success. This is why Mallory's insouciance in 1923 was so captivating. His answer 'because it's there' shrugged off the one thing that was standing in the way of the conquest of the peak, the conviction that it was impossible. It also explains why his answer passed into history.

Keywords: Assemblage. Body without Organs. Mountain Climbing. Intensity. Experience.

\section{Resumo}

Assim como com o conceito de agenciamento, também se tem escrito muito sobre o corpo sem órgãos. Em detrimento do que acontece com o conceito de agenciamento, não há escolas específicas de pensamento associadas ao conceito de corpo sem órgãos, muito menos quaisquer definições determinadas ou específicas, isto é, evidentes. Tal conceito tende a ser utilizado de maneira muito vaga, a maioria das vezes ignorando sua dimensão prática, para se concentrar apenas na estética (Artaud) e nas suas origens filosóficas (Spinoza). No entanto, Deleuze estabelece explicitamente o agenciamento como uma contribuição para a compreensão do comportamento, pelo que, em minha opinião, as observações estritamente filosóficas do corpo sem órgãos, que não dão conta de como ele pode ser usado analiticamente carecem de utilidade. Neste sentido, demonstrar a concepção prática do corpo sem órgãos torna-se uma forma eficaz de entender o próprio conceito. Utilizo, para mostrar esse aspecto, o exemplo da tentativa de George Mallory de escalar o Everest. Argumento que, se nos concentrarmos apenas na conquista simbólica de ser a primeira pessoa a escalar a montanha mais alta do mundo e pensar o ato real de escalada como o preço fundamental que se deve pagar, então efetivamente destruímos por completo a dimensão prática do 
agenciamento, restando apenas uma versão teleológica do mesmo. Agora, pode-se pensar que isso significa que se deve equilibrar a equação focalizando a dimensão corporal da subida, e certamente essa é a direção que precisamos tomar, mas, para isso, precisamos conceber um espaço onde essa dimensão física possa estar registrada em algo que não seja em termos puramente biológicos. Se, como disseram Spinoza e logo Deleuze, não sabemos o que um corpo pode fazer, é porque não temos os meios conceituais de capturar e expressar suas capacidades. Podemos registrar suas conquistas, mas não podemos mapear suas capacidades porque o corpo parece sempre ser capaz de fazer mais do que qualquer um pensou possivel. Até 1953, quando Hillary e Norgay atingiram o cume do Everest, a escalada foi geralmente considerada como impossível. Opinião que foi reforçada por uma dúzia de tentativas fracassadas, para não mencionar as muitas mortes ocasionadas por essas investidas, que precederam o sucesso de Hillary e Norgay. É por isso que a despreocupação de Mallory em 1923 foi tão cativante. Sua resposta "porque está lá" subestimou a única coisa que impedia a conquista da cima, a convicção de que era impossível. Também explica por que sua resposta passou para a história.

Palavras-chave: Agenciamento. Corpo sem órgãos. Alpinismo. Intensidade. Experiência.

\section{Introduction}

If literature is, according to Deleuze, "the attempt to interpret, in an ingenious way, the myths we no longer understand, at the moment we no longer understand them, since we no longer know how to dream them or reproduce them" (DELEUZE, 2004, p. 12), then we can perhaps say that travel writing is literature's primeval attempt to dream extinct myths back into existence. Travellers scour the margins of the earth in search of wonder and in doing so they enflame and revive the collective imagination in two ways: firstly, by creating pictures for the mind of a distinct place, a new set of circumstances that can only be understood in a comparative way (it is either like something we already know, or not like anything we know); secondly, and in many ways much more powerfully, by introducing new forms to the imagination. The latter, so-called mountains of the mind are, as many a travel writer has reported, far more beguiling than the former, the already known 
mountains in atlases and coffee table picture books. There is no genuine traveller who doesn't relish the prospect of walking 'off the map' as George Mallory so aptly put it in his letter home to his wife Ruth describing his first trip to the Himalayas (MACFARLANE, 2003, p. 242). Indeed, so powerful is this fantasy of entering unknown territories, more than one commentator has been moved to lament the loss of mystery that ensues when the veil s finally lifted and the unknown is ushered into the light (MACFARLANE, 2003, p. 232).

The members of the 1921 British Reconnaissance Expedition to Everest (George Mallory was but one of their number, albeit the only one anyone today really remembers), were the first Europeans to set foot in that part of the Himalayas. At that moment, the Himalayas were the greatest of the great unknown mountains, which is why the first expedition party included photographers, geographers and geologists with no real mountaineering experience. Their job was to turn the mountains of the mind into mountains that can be climbed. This hitherto blank space on the map seems to have functioned in a perfectly Lacanian way, acting as an irresistible magnet on the imperial and adventure-minded alike (in the $19^{\text {th }}$ and early $20^{\text {th }}$ century imperialism and adventure went hand in hand - imperialism was the condition for adventure and adventure was the alibi for imperialism). It was like Shel Silverstein's Big O, it called out like a siren to all the missing piece mountaineers, chief among George Mallory, who duly came forward and tried to scale its formidable slopes ${ }^{1}$. If, as Žižek insists, desire is sustained by what it lacks then Robert Macfarlane is undoubtedly correct in saying that "Everest is the greatest of all the mountains of the mind. No mountain has exerted a stronger pull over more imaginations. And no one has been more attracted to Everest than George Mallory." (MACFARLANE, 2003, p. 225). Macfarlane might have said 'fatally attracted' to Everest because as history records Mallory not only died on Everest but he intuitively knew that he would and went

1 I adapt this image from Žižek (2001, p. viii). 
anyway with the resignation of a man at peace with his fate ${ }^{2}$. The really interesting question, then, as Wade Davis argues, is not why did he want to climb Everest, but why despite everything, including the real possibility not just of failure but of death, did Mallory keep going? (DAVIS, 2012, p. 581).

There is something very satisfying about this narrative, all the pieces seem to fit and that by itself ought to be enough to make us suspicious. It is part of the legend of Everest that its very existence is sufficient to command the attention of mountaineers and the admiration by all-comers for those people daring enough to meet its challenge. No-one blinked when Mallory retorted 'because it's there' when he was asked for the umpteenth time why he wanted to climb it because it was understood that that was in fact the reason and that it was a sufficient reason ${ }^{3}$. But it turns out this latter day view of thing is wrong. Mallory's answer wasn't as self-evident as we - I - now assume it to have been ${ }^{4}$. In 1923, when Mallory uttered those words (now regarded as the most famous three words in mountaineering history) to a reporter from the New York Times, climbing Everest wasn't widely regarded as a symbolic achievement worth attaining. Partly this was because it was assumed to be impossible (Mallory had already tried and failed twice when he said it) and therefore not as compelling a symbolic goal as reaching the poles, which had already been accomplished (Cook and Peary reached the north pole in 1908 and Amundsen reached the south pole in 1911). But largely it was because neither the mountain itself nor the idea of climbing had much traction in the popular imagination.

Indeed until 1865, less than 50 years before Mallory uttered his fateful words, Everest didn't even have that name and outside of Tibet and Nepal its existence was known only to a handful of Royal Geographical Society members. It was first sighted by a European in

2 Mallory visited Robert Scott's widow on the eve of his departure for his third and final attempt at scaling Everest and confided in a friend that he didn't think he'd survive the trip. (MACFARLANE, 2003, p. 260).

3 It may not have even been said with such portentous intent. According to one account, Mallory's friends assumed he was being flippant and it was simply the words of an exasperated man in need of a drink. (DAVIS. 2012, p. 466)

4 I used Mallory's famous quote in my essay on assemblage as an illustration of the assemblage's dual structure (BUCHANAN, 2015b). 
1846 when John Armstrong, a member of the Survey of India team, noted its imposing presence from a distance of more than 220 kilometres. At that point in history, western explorers had not traversed the Himalayas in either direction. As such, the entire area was unmapped. It was simply a blank space, as much an obstacle to imperial ambition as it was a bulwark against it (Britain wanted to extend its sphere of influence north of India into Tibet and Nepal in order to defend - preemptively to use a contemporary notion - against the perceived threat of Russian aggression). It wasn't until 1893 that anyone (by which I mean any westerner, but apparently the local people had no interest in seeing it, much less climbing it) attempted to get close to the mountain simply to see it and even then it was from a considerable distance. The idea of climbing Everest was still yet to form itself (DAVIS, 2011, p. 45-46). And it was another decade before the first photographs of Everest reached the west (DAVIS, 2011, p. 64). In the rarefied circles of the Royal Geographical Society in London there was earnest talk of mounting an expedition to Everest from the turn of the 20th century but geography and history was against it. Tibet was off limits to British climbers until 1921, when at last British diplomacy succeeded in gaining them passage. But more than anything else, it was the outbreak of First World War which forestalled any attempts to scale Everest.

Interestingly it was also the war that shaped the first attempts to climb Everest. Expeditions to Everest were explicitly framed as "assaults" and the early expedition parties were largely composed of current or former military personnel (including Mallory himself, who served on the western front). Climbing Everest was made to seem a continuation of war by other symbolic means. But it still took considerable rhetorical labour to transform this imperious peak on the "roof of the world", one of the most isolated and remote places on earth, into the powerful symbol of achievement it is today. Interestingly, it was John Buchan, author of the spy thriller The Thirty-Nine Steps (filmed by Hitchcock) as well as dozens of other novels, who in his capacity as government propagandist helped set the tone. Scaling Everest would, it was said, raise the spirits of generations to come. More than that, it would be a kind of redemption for the horrors of the First World War, a demonstration of 
the Commonwealth's continuing relevance and potency (DAVIS, 2011, p. 109). For the former soldiers, and all those who lost friends and family during the war, it had a different meaning; to them, it stood not for empire, but for something far greater, far more inspiring: to them, Everest was timeless, a symbol of permanence in a time of tumultuous change, an emblem of that which endures despite all the change (DAVIS, 2011, p. 87). Over time, Everest has taken on all these attributes, and many more, but they key point here is that this way of thinking about Everest was manufactured precisely to aid the ambitions of a handful of men who wanted to climb it for their own reasons.

In my haste to latch upon a self-evident illustration of a point I wanted to make about the dual structure of the assemblage, I forgot Jameson's crucial lesson that we should always historicize. I presumed that the symbolic importance of Everest would have been self-evident then as now. At first glance, this seems reasonable enough; after all, it is the tallest mountain in the world, so climbing it must carry significant cachet. So why wouldn't someone like Mallory want to climb it? And why wouldn't people marvel at that ambition? But this assumes that mountain climbing is appealing sui generis and historically this isn't true. It also assumes that people are automatically fascinated by tales of other people climbing mountains and this is similarly untrue. Mountains and mountain climbing are both only comparatively recently fascinating - for most of European history mountains were regarded as impediments. They couldn't be farmed nor easily traversed and generally got in the way of things. As Robert Macfarlane argues in his quite wonderful book Mountains of the Mind Europeans regarded mountains as aesthetically repellent until the mid-1700s (MACFARLANE, 2003, p. 15). Interestingly, their ridges and valleys were said to call to mind the female sex organs and not as might have been expected the phallus (it seems the earth's protuberances we call mountains only became phallic in the aesthetic imagination when men took to climbing them as a pastime in the early 1800s). Not only that, the glorious panoramic view we now automatically associate with mountain climbing as one of its essential raison d'êtres did not have any "currency in the common consciousness" before the late 1700s (MACFARLANE, 2003, p. 145). 
Indeed, as Macfarlane notes, some travellers compelled to journey through high Alpine passes even preferred to be blindfolded rather than see the vistas below.

My point then is that Everest wasn't, and of course still isn't, a self-evident symbol of anything. Its meaning is the product of spin. One of Deleuze and Guattari's most important insights in this regard, which hasn't really been dealt with in the secondary literature, is that the two formations that together comprise the assemblage - the form of content and the form of expression - are formed independently of each other. The mountaineers' perception that the mountain is worth climbing because it would be hard to climb and therefore should be climbed was formed independently of the spin that government bodies created in order to open the way for the climb to happen - they invested in the climb for their own political reasons, reasons which pre-existed the climb and simply used this as a vehicle for their ambitions. The same set of reasons drove Robert Scott to his death in trying to reach the south pole and cost Ernest Shackelton his life as he attempted to circumnavigate the globe pole to pole (a feat later achieved by Ranulf Fiennes who, as it happens, is also the oldest person to climb Everest). This in turn points to something else that I didn't make clear enough in my essay on the assemblage and that is the fact that the relation between content (the difficulty of climbing Everest) and expression (the meaning associated with climbing the mountain) is not only independent, but also arbitrary. One can say that it is obvious that climbing the world's highest mountain should carry significant cachet, but what isn't obvious is the nature of that cachet. In Mallory's time it was linked to the glory of the British Empire, whereas today it is more about the triumph of the human spirit.

Deleuze and Guattari define the relationship between content and expression as a reciprocal presupposition, but in so doing they tend to gloss over their more radical point which is that it is also arbitrary. There is no intrinsic reason why the fact that Everest is the highest peak in the world should be of any interest to anyone, just as there is no reason why in being so it should be a symbol of achievement 
or redemption. And as I've already discussed, for a very long period Everest was of no interest to anyone in the west and the idea of climbing it meant nothing to most people. Its meaning had to be manufactured. But even taking into account the prodigious ideological and rhetorical labour that went into fashioning Everest as the symbol it is, it still doesn't explain why Mallory himself felt drawn to Everest. If his only goal was to ink his name into the record books then why climb Everest? Of all the possible challenges he could have set himself, why that one? Certainly being the first to climb the world's highest mountain would have brought him lasting fame had he succeeded, but it seems doubtful that this was his sole or even principal motivation because it ignores the specificity of the challenge itself (the difficulty of the ascent, the cold, the bad weather, oxygen deprivation, and so on). My point is that even if we can understand the desire to be known as the first person to climb the highest peak in the world that does not mean we can assume we understand the desire to put oneself through the rigours and dangers of the actual climb. This is the point, then, where our thinking about the assemblage needs to be connected to the body without organs.

Like the concept of the assemblage, the body without organs is much written about, though perhaps not to the same extent as the assemblage (which as I noted previously has generated more than 8000 articles already). Unlike the assemblage, however, there are no specific schools of thought associated with the body without organs (neither DeLanda nor Latour seem to have any use for it), much less any agreed definitions ${ }^{5}$. For the most part it is used in a very vague manner, or, what amounts to the same thing, in a way that simply recites the concept as so much jargon without trying to generate any new understanding of it. In my own work, I have suggested that the body without organs can usefully be compared to Bourdieu's concept of the habitus

5 This is perhaps not surprising given that Deleuze and Guattari were not sure themselves if they each meant the same thing by the term body without organs. They were perhaps being tongue in cheek when they said this, but the fact is the concept does evolve from its first iteration in the Logic of Sense to its final form in What is Philosophy? See Buchanan 2014. 
(BUCHANAN, 2014) ${ }^{6}$. This connection is, I now believe, something of a false start, but it has the virtue of forcing me to think more concretely about the practical nature of the body without organs. As I've said, Deleuze quite explicitly positions the assemblage as a contribution to an understanding of behaviour, so the purely philosophical accounts of the body without organs that give no account of how it can be used analytically are not helpful in my view.

In philosophical terms, if we focus only on the symbolic attainment of being the first person to climb the world's tallest mountain and consign the actual act of climbing to the realm of mere entry price, then we effectively destroy the assemblage by rendering it teleological. Now, one might think that this means one should balance the equation by focusing on the bodily dimension of the climb, and certainly that is the direction we need to take, but to do that we need to conceive of a space where that physical dimension can be registered in something other than purely biological terms. If, as Spinoza and after him Deleuze have argued, we do not know what a body can do, it is because we do not have the conceptual means of capturing and expressing its capabilities. We can record its achievements, but we cannot map its capabilities because the body seems always to be capable of doing more than anyone thought possible. Until 1953 when Hillary and Norgay reached the peak of Everest climbing Everest was generally regarded as impossible. A view that was reinforced by the dozen or so failed attempts, not to mention the many deaths occasioned by those attempts, that preceded Hillary and Norgay' success. This is why Mallory's insouciance in 1923 was so captivating. His answer "because it's there" shrugged off the one thing that was standing in the way of the conquest

6 My aim was to try to triangulate a definition that could be deployed for analytic purposes. I now think this was off target - my original thinking was that the body without organs could be understood as an acquired disposition like the habitus, because in many ways that is how it seems to function. For example, when Artaud chooses madness over sanity that could be seen as his disposition speaking. I now think this is mistaken for two reasons: firstly, the body without organs isn't acquired, it is produced, which isn't the same thing because the body without organs isn't enduring; secondly, the body without organs is something we feel and know in an immediate way whereas our disposition is largely unknowable to us - it manifests in our thoughts and actions without us being aware of its presence. 
of the peak, the conviction that it was impossible. It also explains why his answer passed into history.

In more recent work on the body without organs I have argued that the central question posed by this concept is: what makes a particular state of being desirable in itself? (BUCHANAN, 2015) Returning to Mallory, this means the question, why did he want to climb Everest is somewhat beside the point. It is too teleological, too focused on ends and means and not attentive enough to the intensities of the actual experience of traversing an unknown and potentially unknowable space. Even before Mallory made his first attempt it was already thought that humans could not cope with the altitude and the fact that because of the reduced air pressure less than a third of the oxygen required to sustain life would be available. Interestingly, despite knowing this, the first three climbing teams generally took the view that using oxygen tanks would somehow amount to cheating and gave little thought to the technical requirements of using oxygen. Then there is the weather, which is extremely changeable and for most of the year quite inhospitable to humans. Winds of over $280 \mathrm{~km}$ ph have been recorded on the mountain. The weather is so fierce there are really only a couple of weeks in May each year when it is feasible to attempt the summit. And even then dozens of climbers have been caught in bad weather and perished on the mountain top, their bodies left where they fell because of the extreme difficulty of extracting them. Of the 400 people who have died on Everest's slopes, at least half are still there, frozen in place, steadily becoming part of the landscape, their corpses serving as way markers for future climbers. Among them is Mallory's body, discovered in 1999, only a few hundred feet from the summit, thus fuelling speculation he made the peak before dying.

The body without organs, which Deleuze and Guattari repeatedly say isn't a concept, thus further complicating matters, has gone through at least three phases of development: the first two, in Logic of Sense and Anti-Oedipus were largely negative, describing something I hesitate to call a pathological state of being, namely the catatonic state of schizophrenics following a psychotic breakdown; it was only with $A$ Thousand Plateaus that an affirmative model of the body without organs 
that could be considered useful in analytic sense began to emerge. And even then, within the span of the 500 odd pages of $A$ Thousand Plateaus the notion evolves further, separating itself from strictly psychological questions, becoming the plane of immanence. By the time one gets to What is Philosophy? the body without organs has more or less disappeared as a term, only its final incarnation as the plane of immanence remains. It is the middle incarnation of the body without organs as a psychological concept that interests me. Deleuze and Guattari use several examples to illustrate it, drawing on a range of works from writers like Artaud and Burroughs, but none are more vivid nor more vividly illustrative than that of the masochist case notes they extract from Michel M'uzan. "Mistress, 1) You may tie me down on the table, ropes drawn tight for ten to fifteen minutes, time enough to prepare the instruments; 2) One hundred lashes at least, a pause of several minutes; 3) You begin sewing ..." (DELEUZE; GUATTARI, 1987, p. 167). And so it goes on, each step more painful, more humiliating, and more physically constricting than the one that went before. Together these steps constitute the assemblage, but they are underpinned by a program, which is the abstract machine, and what they create is a body without organs.

The key question then is not so much how does one make a body without organs (the title Deleuze and Guattari give to the chapter they devote to this concept in A Thousand Plateaus), but what happens there once one has been made. The first question isn't altogether irrelevant because as the masochist case makes clear, the body without organs isn't arrived at by accident, one has to have a program or plan. Tie me up, whip me, climb a mountain, and so on. There are no guarantees, though, plans can fail and go awry (the mountain can kill you). Even so, as Deleuze and Guattari famously said in Anti-Oedipus, the crucial question is always the pragmatic one of how does it work? Rejecting standard psychoanalytic interpretations of masochism as a fantasyformation, Deleuze and Guattari argue that it is "false to say that the masochist is looking for pain but just as false to say that he is looking for pleasure in a particularly suspensive or roundabout way. The masochist is looking for a type of $\mathrm{BwO}$ that only pain can fill, or travel over, 
due to the very conditions under which that BwO was constituted" (DELEUZE and GUATTARI, 1987, p. 168). To which they add, "Pains are populations, packs, modes of king-masochist-in-the-desert that he engenders and augments." (DELEUZE and GUATTARI, 1987, p. 168). Thus for every body without organs there are always two questions: (1) how was it made? and (2) what are its modes? These questions, in turn, imply an ethics of the body without organs: there are good, productive types of bodies without organs and bad, cancerous types of bodies without organs and the key task of the schizoanalyst is to distinguish between the two and figure out how to transform the cancerous bodies without organs into productive bodies without organs (DELEUZE and GUATTARI, 1987, p. 180-181).

The problem Deleuze and Guattari have with most accounts of masochism (to continue with this example, whose relevance will become clear momentarily), particularly Freud's accounts of it in his essays on sexuality, is that they all tend to assume that the pain masochists seek out and experience is a substitute for some other kind of experience. The conventional idea, which Deleuze and Guattari strenuously reject, that masochists obtain pleasure from pain is a perfect case in point. It assumes that pain cannot be desired for itself, but must somehow be a substitute for, a better still a perverse or counter-intuitive pathway to something that is usually considered to be desirable in and of itself. By contrast, Deleuze and Guattari want to understand how and why pain might be desired for itself and not as a substitute for something else. But they also wonder what this pain does for the person who seeks to experience it, what are its effects? This line of questioning takes us from the specific body without organs of the masochist to the abstract body without organs in general - what exactly is a body without organs? Deleuze and Guattari are much clearer on the first question, how the body without organs works in an immanent sense than they are the second question of why we might need one at all. What do they mean when they say we cannot desire without one? What does this tell us about desire? I want to finish by pointing to two further remarks by Deleuze that might help us answer this question. The first is one Deleuze and Guattari draw from Henry Miller, namely 
whether or not it is possible to get drunk on pure water and the second is Deleuze's discussion of the "death scen" that isn't a death scene in Dickens.

One of Deleuze and Guattari's key questions, which we might categorize as a therapeutic, is whether or not the effects (not affects) obtained from one body without organs can be obtained by other means, ie via a different assemblage. Thus if one could get drunk on pure water one could avoid the toxicity of alcohol and nevertheless obtain the same desirable effects. What Deleuze and Guattari don't say a lot about, though, is what those effects are, save that, in the case of drugs, it brings about an altered form of perception, one more attune to molecularity than sober forms of perception. But I would argue this is more a matter of affects than effects. This brings me to the second text, Deleuze's essay on pure immanence, reputedly the last thing he wrote (whether that is the case, we'll never know I suppose, but we do know it was the last thing he published). Deleuze describes the moment between life and death, the moment when people think Riderhood is dying and don't yet know he isn't dying, as a life. He writes, in this moment the "life of the individual gives way to an impersonal and yet singular life that releases a pure event freed from the accidents of internal and external life, that is, from the subjectivity and objectivity of what happens" (DELEUZE, 2001, p. 28). This, I want to suggest, is the body without organs in its abstract form.

How can we interpret this in a way that is analytically useful? Let us return then to the case of Mallory. By his own admission Everest possessed him and even when he sensed it would be the death of him he didn't turn away from it (DAVIS, 2012, p. 275). Macfarlane tries to explain Mallory's actions by positioning Everest as his lover, but even if we accepted this explanation - which I do not - it still begs more questions than it answers (MACFARLANE, 2003, p. 245). It doesn't explain how the thought of climbing a mountain can possess one to the point of suicide. His other, more general answer, is that climbers climb in search of the sublime. This, it seems to me, is more promising, but only if we interpret the sublime as the name of a specific kind of intensity, a feeling of fear, exhilaration and exaltation that has no proper 
name of its own. My interest in this kind of writing is precisely to see how writers come to grips with this basically inexpressible sensation and it seems to me that we crush its intensities by labelling it sublime. One see why Deleuze and Guattari preferred apparently nonsensical terms like becoming-animal to global terms like sublime, they give intensities the space to live and breathe, to challenge and confuse us.

The desire to climb Everest is thus the desire to create a body without organs on which certain kinds of intensities - usually referred to as feelings of the sublime - can circulate. These intensities, which taken together are described as lines of flight, can move in one of three directions, according to Deleuze and Guattari: transformation, the illusion of transformation and death. Analysis thus needs to ask two questions: why is this particular formation of a body without organs desire and what is the modality of the intensities circulating on it - will they lead to a positive change or death?

\section{References}

BUCHANAN, I. The Structural Necessity of the Body without Organs. In: I Buchanan, A Tynan and T Matts (eds). Deleuze and the Schizoanalysis of Literature. London: Bloomsbury, 2015a, p. 24-42.

BUCHANAN, I. Assemblage Theory and its Discontents. Deleuze Studies, v. 9, n. 3, p. 382-392, 2015 b.

BUCHANAN, I. Body without Organs. In: P Ardoin, L Mattison and S Gontarski (eds). Understanding Deleuze, Understanding Modernism. London: Bloomsbury, 2014. p. 255-257.

BUCHANAN, I. Deleuze and Guattari's Anti-Oedipus. London: Continuum, 2008.

BUCHANAN, I. Deleuze and Ethics. Deleuze Studies, v. 5, n. 4, p. 7-20, 2011.

BUCHANAN, I. Little Hans Assemblage. Visual Arts Research, 40, p. 9-17, 2013. 
DAVIS, W. Into the Silence: The Great War, Mallory and the Conquest of Everest. London: Vintage Books, 2012.

DELANDA, M. A New Philosophy of Society: Assemblage Theory and Social Complexity. London: Continuum, 2006.

DELEUZE, G. Desert Islands and Other Texts 1953-1974, trans M Taormina. Cambridge: MIT Press, 2004.

DELEUZE, G. Pure Immanence: An Essay on Life, trans A Boyman. NY: Zone Books, 2001.

DELEUZE, G. Difference and Repetition, trans P Patton. London: Athlone, 1994.

DELEUZE, G.; GUATTARI F. Anti-Oedipus: Capitalism and Schizophrenia, trans R. Hurley et al. London: Athlone, 1983.

DELEUZE, G.; GUATTARI F. What is Philosophy? trans H Tomlinson and G Burchell. London: Verso, 1994.

MACFARLANE, R. Mountains of the Mind: A History of a Fascination. London: Granta, 2003.

ŽIŽEK, S. Enjoy Your Symptom. London: Routledge, 2001.

Received: 12/14/2016

Recebido: 14/12/2016

Approved: 08/02/2017

Aprovado: 02/08/2017 